\title{
Design Development and Heat Transfer Analysis of a Triple Concentric Tube Heat Exchanger
}

\author{
Dilpak Saurabh P. ${ }^{*}$, Pradip K. Tamkhade ${ }^{\ddagger}$ and Mandar M. Lele ${ }^{\dagger}$ \\ †Mechanical Engg. Department, MAEER's MIT College of Engineering, Savitribai Phule Pune University, Pune, India \\ ‡Mechanical Engg. Department, Marathwada Mitra Mandal's College of Engineering, Savitribai Phule Pune University, Pune, India \\ Accepted 15 June 2016, Available online 20 June 2016, Special Issue-5 (June 2016)
}

\begin{abstract}
The present study includes design development of a triple concentric tube heat exchanger for oil cooling application. CFD analysis of the heat transfer between fluids and also experimental investigation of the heat transfer through the heat exchanger having Water-Oil-Water combination i.e. water flowing in the inner tube and the outer annulus and oil through the inner annulus is carried out. Theoretical studies are carried out for numerical simulations and evaluation of heat transfer rate. The Triple Concentric Tube Heat Exchanger is to be evaluated experimentally for temperature variation along its length. CFD analysis is used to validate the analytical design.
\end{abstract}

Keywords: Triple Concentric Tube Heat Exchanger, Design Development, CFD Analysis, Water-Oil-Water combination.

\section{Introduction}

Different products use Triple concentric-tube heat exchangers. Almost all liquid products can be pasteurized through one of these heat exchangers. Examples of such products are milk, cream, pulpy orange juice, mashes, eggs, etc. Triple concentric-tube heat exchangers improve the heat transfer.

Basically a triple concentric tube heat exchanger consists of three tubes concentrically placed within each other. Thus, we have called these tubes as-inner tube, intermediate tube and outer tube. The Heat exchanger consists of inner tube space, inner annular space and outer annular space.

The efficiency that a triple tube heat exchanger gives is higher to that of a double tube heat exchanger. Heat exchangers have been used for air conditioning, heating applications, power production, waste heat recovery, and chemical processing [F. P. Incropera et al. (1990)]. Further, heat exchangers are used for pasteurization sterilization, drying, evaporation, cooling, and freezing purposes. Heat exchangers have been classified based on flow directions (parallel-flow, cross-flow and counter-flow), construction of the heat exchanger (tubular or plate heat exchangers), on the basis of contact between the fluids (direct/indirect contact type). The type of heat exchanger to be used is determined by the process and the product specifications. Various physical characteristics of the material/fluid influence the performance of the heat exchanger.

\section{Literature Survey}

G.A. Quadir et al. (2014) carried out the investigation for the performance of a TCTHE using finite element method under steady state conditions for different flow arrangements and for insulated and non-insulated conditions of the heat exchanger. The three fluids considered were hot water, cold water and the normal tap water. They carried out experimentation on a triple concentric pipe heat exchanger under steady state conditions for two different flow arrangements and for insulated and non-insulated conditions of the heat exchanger.

0. García-Valladares (2004) developed a detailed 1D steady and transient numerical simulation of the thermal and dynamic behaviour of TCTHE. The governing equations inside the inner tube and the annulus (inner and outer), with the energy equations in the tube walls and insulation, are solved. The discretized governing equations with fluid flow are coupled using an implicit step by step method.

Birol Basal and Ahmet Unal(2013) proposed a new type of thermal energy storage system that consisted of a triple concentric-tube arrangement in this study for enhancement of the storage performance. For that purpose, a numerical investigation was conducted. They used enthalpy method for same. Based on the numerical calculations, the effects of system parameters such as mass flow rate and the inlet temperature of the heat transfer fluid and the variation of the tube radii on the system performance are investigated. The results indicated that, a significant

${ }^{*}$ Corresponding author: Dilpak Saurabh P. 
enhancement in the system performance can be achieved by replacing classical hollow cylinder type storage with the presently proposed triple concentrictube storage system.

M. Bernardi et al.(2009) investigated the steadystate heat transfer in laminar flow of liquid egg yolk. It is a pseudoplastic fluid food. He investigated it in circular and concentric annular ducts experimentally. The average convection heat transfer coefficients were used to obtain new empirical expressions for estimating the Nusselt numbers for fully developed flows at the thermal entrance of the geometries. The comparisons with existing correlations for Newtonian and non-Newtonian fluids were in agreement with each other to good extent.

The thermal resistance and the heat exchanger effectiveness relations are well explained by Guo et al (2005). He added a tube to a double concentric tube heat exchanger converting it to a triple tube one and he concludes that the latter performs better compared to the prior one.

The similar approach was adopted for the heat treatment of milk in a helical triple tube heat exchanger by Nema and Datta (2006). The thermal performance for a TCTHE for both cases of co-current and countercurrent flow arrangements is by Saeid and Seetharamu (2006) which is restricted to insulated conditions.

Krishna et al. (2013) investigated the effect of longitudinal heat conduction in the separating walls on the performance of a cryogenic heat exchanger having thermal interaction between three fluids and the effect of heat to the cold fluid in leak in a three-fluid heat exchanger of non-concentric type using the analytical method and FEM.

\section{Assumptions for design}

The assumptions for the designing of heat exchanger are as follows-

1. Water flows in the inner tube and outer annular space; the flow is parallel and in same direction.

2. There is no phase transformation in the fluids during heat transfer.

3. There is no fouling in the TCTHE.

4. Conductional resistance of the tube material is negligible.

5. Flow is continuous, uniform and steady.

\section{Considerations for design}

The considerations for designing of the heat exchanger are as follows-

1. The heat exchanger is designed to cool oil from $85^{\circ} \mathrm{C}$ to $55^{\circ} \mathrm{C}$.

2. The inlet temperatures of water are same and ambient (here, assumed $30^{\circ} \mathrm{C}$ ) and the flow rates of them are also same.

3. Oil (ISO VG 22 grade) flows in the inner annular space; the direction of flow of oil is opposite to that of water. Thus, our flow condition is counter current flow.
4. The operating and geometric parameters of the TCTHE are as mentioned in Table 1

Table 1 Input parameters

\begin{tabular}{|c|c|c|}
\hline Inner tube diameter (OD) & $\mathrm{d}_{1 \mathrm{o}}$ & $0.0381 \mathrm{~m}$ \\
\hline Intermediate diameter (OD) & $\mathrm{D}_{2 \mathrm{o}}$ & $0.0508 \mathrm{~m}$ \\
\hline Outer diameter (OD) & $\mathrm{D}_{3 \mathrm{o}}$ & $0.0762 \mathrm{~m}$ \\
\hline Thickness of tube & $\mathrm{t}$ & $0.0015 \mathrm{~m}$ \\
\hline Load & $\mathrm{Q}$ & $14.3 \mathrm{~kW}$ \\
\hline Water1 inlet temperature & $\mathrm{T}_{\mathrm{w} 1 \mathrm{i}}$ & $30^{\circ} \mathrm{C}$ \\
\hline $\begin{array}{c}\text { Oil (ISO VG 22) inlet } \\
\text { temperature }\end{array}$ & $\mathrm{T}_{\mathrm{oi}}$ & $85^{\circ} \mathrm{C}$ \\
\hline Water2 inlet temperature & $\mathrm{T}_{\mathrm{w} 2 \mathrm{i}}$ & $30^{\circ} \mathrm{C}$ \\
\hline Oil outlet temperature & $\mathrm{T}_{\mathrm{oo}}$ & $55^{\circ} \mathrm{C}$ \\
\hline Volumetric flow rate of water & $\mathrm{V}_{\mathrm{w}}$ & $4 \mathrm{~m}^{3} / \mathrm{h}$ \\
\hline Volumetric flow rate of oil & $\mathrm{V}_{\mathrm{o}}$ & $1 \mathrm{~m}^{3} / \mathrm{h}$ \\
\hline Specific heat of water & $\mathrm{C}_{\mathrm{pw}}$ & $4180 \mathrm{~J} / \mathrm{kgK}$ \\
\hline Specific heat of oil & $\mathrm{C}_{\mathrm{po}}$ & $2040 \mathrm{~J} / \mathrm{kgK}$ \\
\hline Thermal conductivity of water & $\mathrm{k}_{\mathrm{w}}$ & $0.618 \mathrm{~W} / \mathrm{mK}$ \\
\hline Thermal conductivity of oil & $\mathrm{k}_{\mathrm{o}}$ & $0.129 \mathrm{~W} / \mathrm{mK}$ \\
\hline Thermal conductivity of steel & $\mathrm{k}_{\mathrm{steel}}$ & $16 \mathrm{~W} / \mathrm{mK}$ \\
\hline Dynamic viscosity of water & $\mu_{\mathrm{w}}$ & $0.0008 \mathrm{~kg} / \mathrm{ms}$ \\
\hline Dynamic viscosity of oil & $\mu_{\mathrm{o}}$ & $0.00803 \mathrm{~kg} / \mathrm{ms}$ \\
\hline
\end{tabular}

\section{Design Development Procedure}

The schematic of the TCTHE is shown in Figure 1.

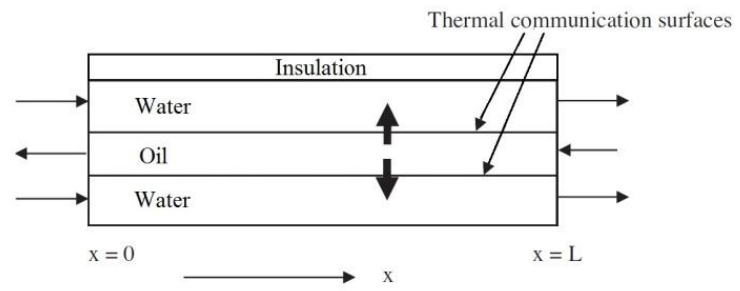

Figure 1 Schematic of a TCTHE

A triple concentric tube heat exchanger has to be designed for the given conditions. For calculating the geometrical parameters viz. tube diameters, thicknesses and length for given conditions, a computer based design model (program) was developed using MATLAB. Using the program various combinations were checked for feasible dimensions. Program was run for many dimensions, of which one set of diameters, as given in input parameters in Table 1 , was finalised because it gave feasible length; such that its fabricating and portability is convenient.

LMTD method was used for design procedure of the triple concentric tube heat exchanger. LMTD method uses the following steps

1) Using energy balance calculate the unknown outlet temperatures of water in inner and outer tubes.

2) Convective heat transfer coefficients are determined for all tubes from physical properties of fluids.

3) Two overall heat transfer coefficients are calculated based on outside area of the inner tube and on inside area of intermediate tube. 
4) Calculate the two LMTDs (Logarithmic mean Temperature Differences) for counter current flow in our case using inlet outlet temperatures.

5) Finally, calculate the length of heat exchanger by using equation- $\mathrm{mC}_{\mathrm{p}}\left(\mathrm{T}_{\mathrm{oi}}-\mathrm{T}_{\mathrm{oo}}\right)=\mathrm{U}_{1} \pi \mathrm{d}_{1 \mathrm{o}} \mathrm{L} \Delta \mathrm{T}_{\operatorname{lm} 1}+$ $\mathrm{U}_{2} \pi \mathrm{d}_{2 \mathrm{i}} \mathrm{L} \Delta \mathrm{T}_{\operatorname{lm} 2}$

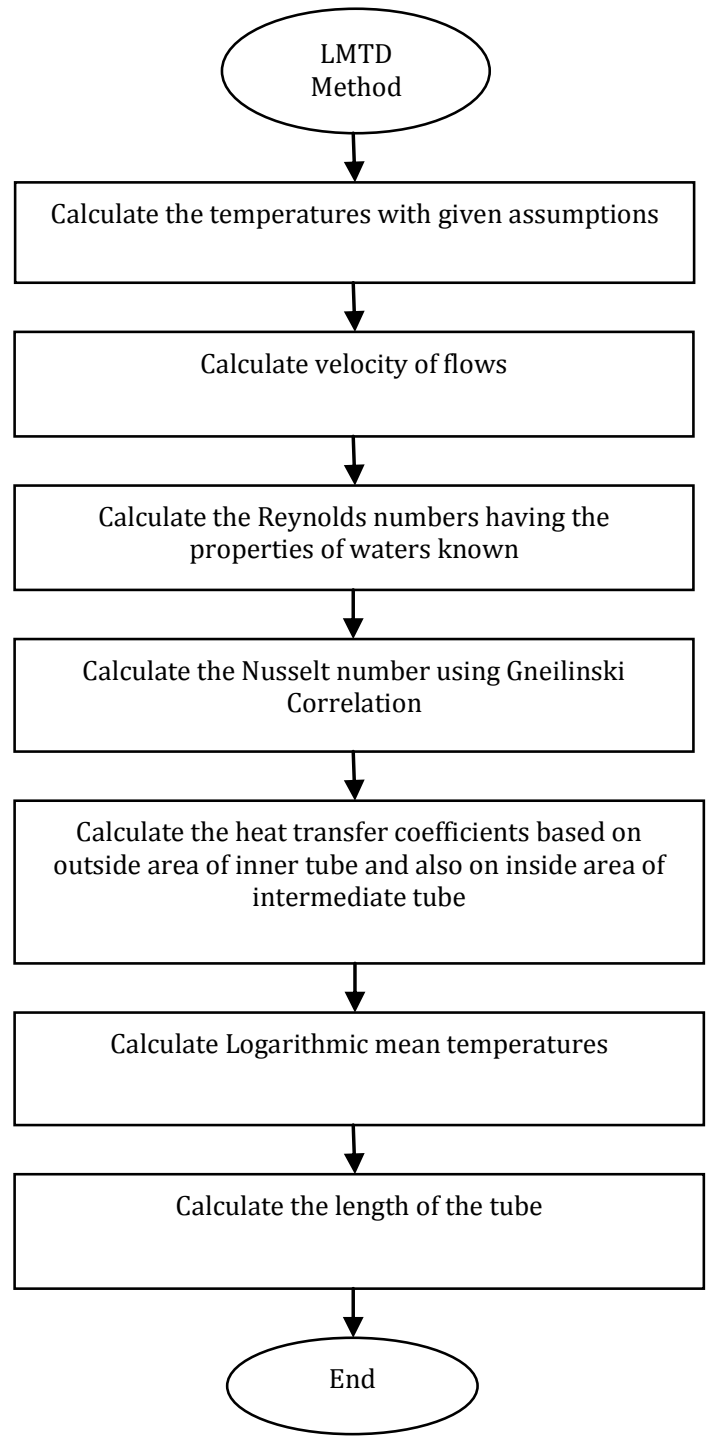

\section{CFD Analysis}

The geometry using the calculated geometrical dimensions. The software used for CFD analysis is ANSYS Workbench. Modelling was done in ICEM; meshing was done using ICEM only; simulations were carried out in FLUENT. CFD Post was used for respective graphics of temperature contours, streamlines, volume rendering, planar heat distribution graphics, etc.

\subsection{Modelling}

Model of the TCTHE was created in ICEM. The dimensions of the model were as specified in Table 1. However, the length of the TCTHE was rounded off to $2 \mathrm{~m}$. The model is as shown in Figure 2.

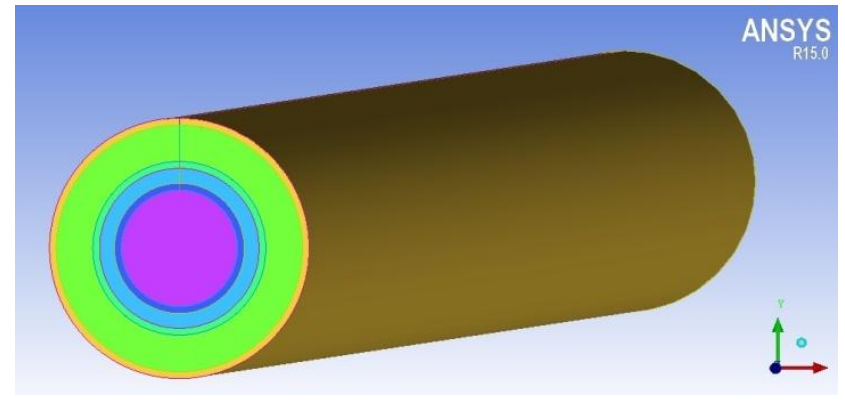

Figure 2 Model of TCTHE in ICEM

\subsection{Meshing}

Block meshing was used to mesh our geometry. Block meshing uses blocks to cover the whole geometry. These blocks are then split. Meshing was done using block meshing and the total mesh count was adjusted to around 1.7 million so that the simulation is run in our system conveniently. The meshing is shown in Figure 3.

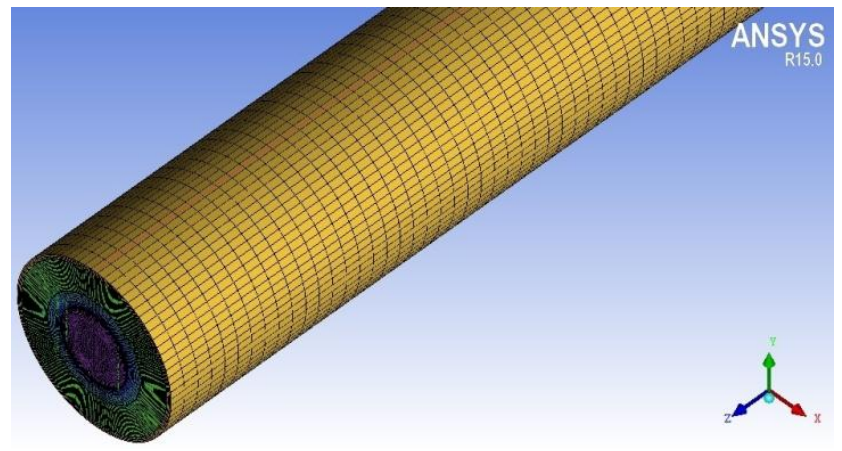

Figure 3 Meshed model

\subsection{Simulation}

The simulation of the model was run in FLUENT solver. The $\mathrm{k}-\varepsilon$ realizable model was used to solve the simulation. Boundary conditions were specified; various other requirements like temperature inlets and outlets, flow velocity, material properties of all material used viz. stainless steel for tubes, water, ISO VG 22 oil. Our main aim was to check the outlet temperatures of both water and oil. The heat balance of the process was checked. If the heat balance is zero our heat transfer process is acceptable and technically sound. Here, the heat balance gives a difference of 0.26 $\mathrm{W}$; which is close to zero. Thus, our heat balance is achieved.

\subsubsection{Temperature contours}

Temperature contours for flow of water in the innermost tube, temperature contour for flow of oil in the intermediate tube and that of water in the outermost annulus is shown in figure 5,6,7 respectively. 


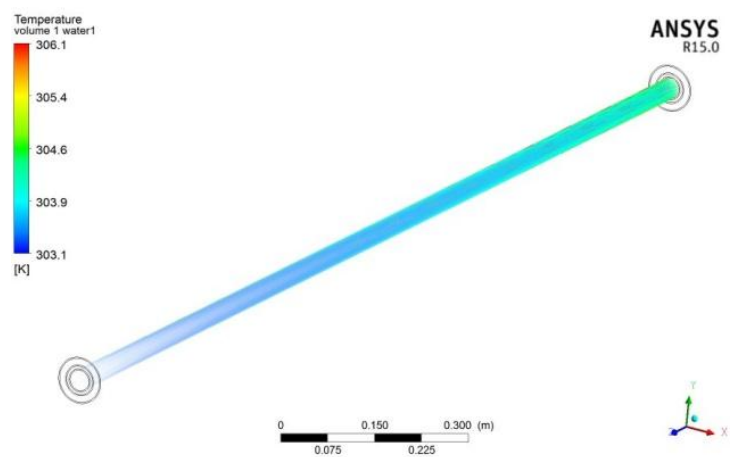

Figure 4 Temperature contour of inner tube carrying water

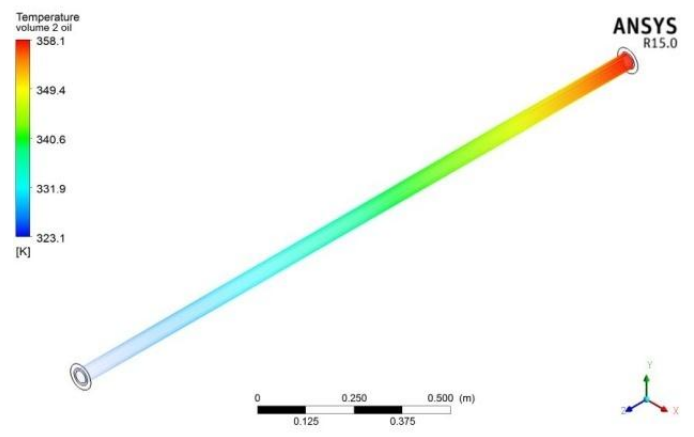

Figure 5 Temperature contour of inner annulus carrying oil

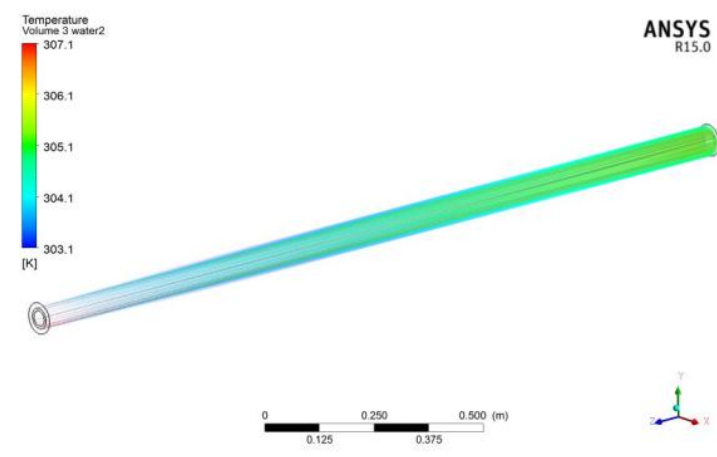

Figure 6 Temperature contour of outer annulus carrying water

\subsection{CFD Results}

Above discussion much talks about the results achieved by CFD analysis. However, the temperature results are given in Table 2 . We see results are close to analytical calculations. The minute difference might be due to calculation errors like rounding off, etc. However, our aim seems achieved through CFD. Thus, CFD results permit us to go ahead with fabrication.

Table 2 CFD Results for temperatures

\begin{tabular}{|l|c|c|}
\hline \multicolumn{1}{|c|}{ Area } & $\begin{array}{c}\text { Inlet } \\
\text { temperature }\end{array}$ & $\begin{array}{c}\text { Outlet } \\
\text { temperature }\end{array}$ \\
\hline Water(inner tube) & $30^{\circ} \mathrm{C}$ & $31.3^{\circ} \mathrm{C}$ \\
\hline Oil (inner annulus) & $85^{\circ} \mathrm{C}$ & $51.3^{\circ} \mathrm{C}$ \\
\hline Water(outer annulus) & $30^{\circ} \mathrm{C}$ & $32.63^{\circ} \mathrm{C}$ \\
\hline
\end{tabular}

\section{Fabrication, System Integration and Experimental Investigation}

\subsection{Experimental Setup}

Experimentation on the TCTHE was carried out in order to predict the thermal performance of the three concentric tube heat exchanger, the outlet temperatures of all the fluids flowing through the heat exchanger are to be seen. Experiment was conducted by fabricating the triple tube heat exchanger subjected to two fluids i.e. water and oil; water flowing in inner tube and outer annulus and oil flowing through inner annulus of the heat exchanger. A triple concentric tube heat exchanger was fabricated for experimentation. The three tubes used are made of stainless steel 304 . Outside diameters of the three tubes are $0.0381 \mathrm{~m}$, $0.0508 \mathrm{~m}$ and $0.0762 \mathrm{~m}$ respectively with thickness of each tube as $2 \mathrm{~mm}$ only. The two fluids are pumped from two different tanks to the heat exchanger as shown in Figure 8. The arrangement of flow of different fluids is called W-O-W (Water-Oil-Water) configuration of the heat exchanger as shown in Fig. 8. The flow is counter current i.e. water flows in one direction and oil flows in the opposite direction.

Oil is at inlet temperature $85^{\circ} \mathrm{C}$. Oil of grade ISO VG 22 is used. Heater of $6000 \mathrm{~W}$ is used to heat oil to this temperature. The water and oil starts flowing from the tank through the pump, passes through the Rotameter measuring the volume flowrates, and enters the heat exchanger inlet. 15 number of PT100 Class A temperature sensors are used to measure the temperature variation along the length of the heat exchanger. The positions for the sensors are eqidistant along length. For each fluid, two temperature sensors at entry and exit and three temperature sensors placed equidistant from the entry or exit of the heat exchanger are mounted. In order to take the readings of temperature, 3 units of 6 channel digital indicators were used. All the temperature readings were taken only after they were stable as shown by the Indicators.

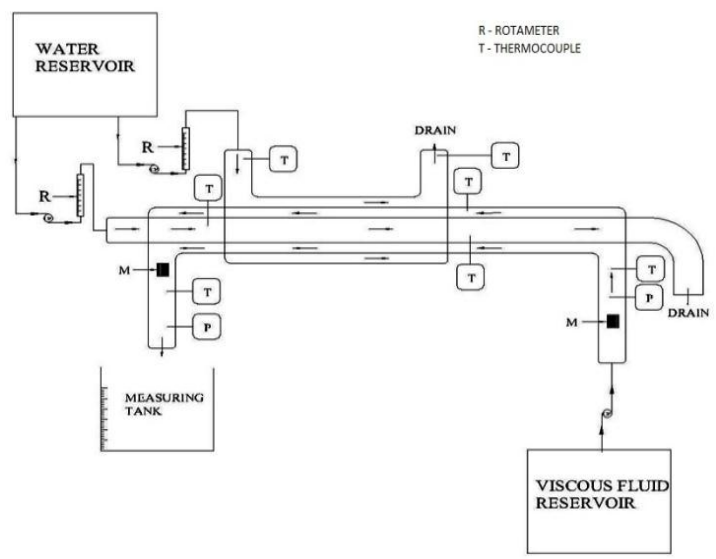

Figure 7 Experimental setup

\subsection{Results of Experimentation}

The first set of experimental results in terms of temperature variations of different fluids along the 
length of the heat exchanger for counter current flow under $\mathrm{W}-\mathrm{O}-\mathrm{W}$ arrangement for temperature variation in oil, water 1 and water 2 is presented in Fig. 9, 10 and 11 respectively when the volume flow rates of the three fluids are as follows, i.e. $V_{w 1}=V_{w 2}=1 \mathbf{m}^{3} / \mathbf{h}$ (16.67 $\mathrm{l} / \mathrm{min})$ and $V_{\text {oil }}=4 \mathrm{~m}^{3} / \mathrm{h}(66.67 \mathrm{l} / \mathrm{min})$,

It is observed that the water 1 temperature rises to $31.5^{\circ} \mathrm{C}$ from its entry temperature of $30^{\circ} \mathrm{C}$; the oil temperature drops to $53^{\circ} \mathrm{C}$ from its entry temperature of $85^{\circ} \mathrm{C}$ and the water 2 temperatures increases to $32.1^{\circ} \mathrm{C}$ from its entry temperature of $30^{\circ} \mathrm{C}$ due to the heat exchange between the fluids.

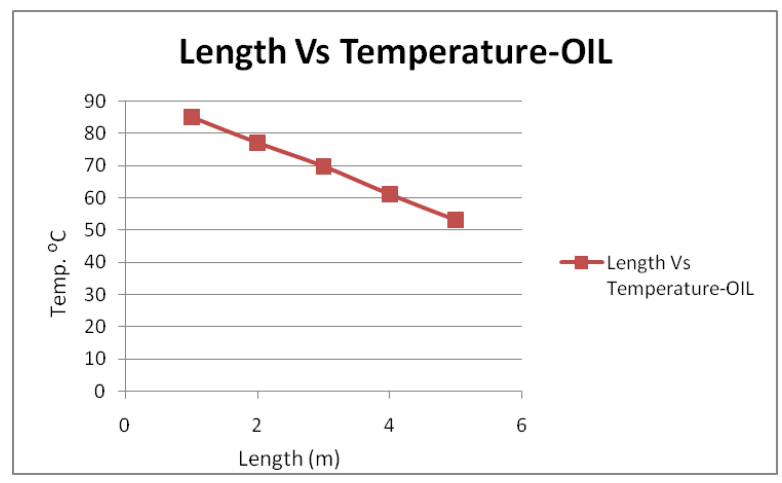

Figure 8 Temperature distribution of oil along the length of heat exchanger

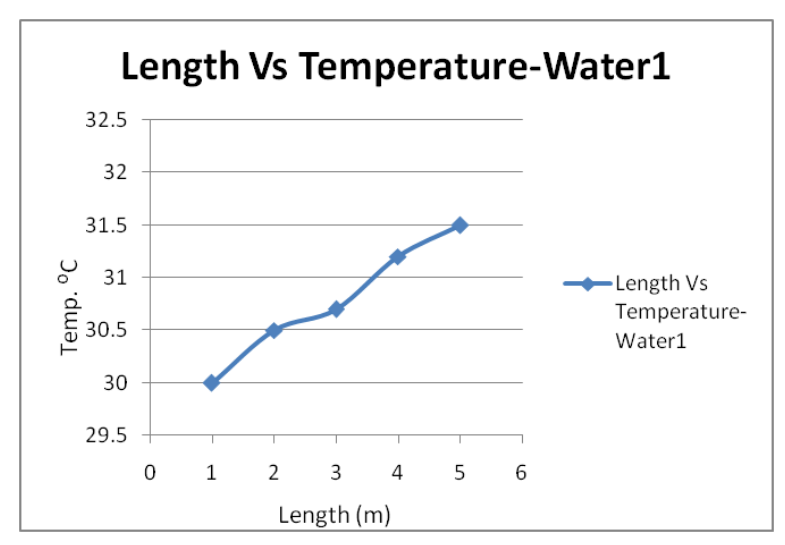

Figure 9 Temperature distribution of water1 along the length of heat exchanger

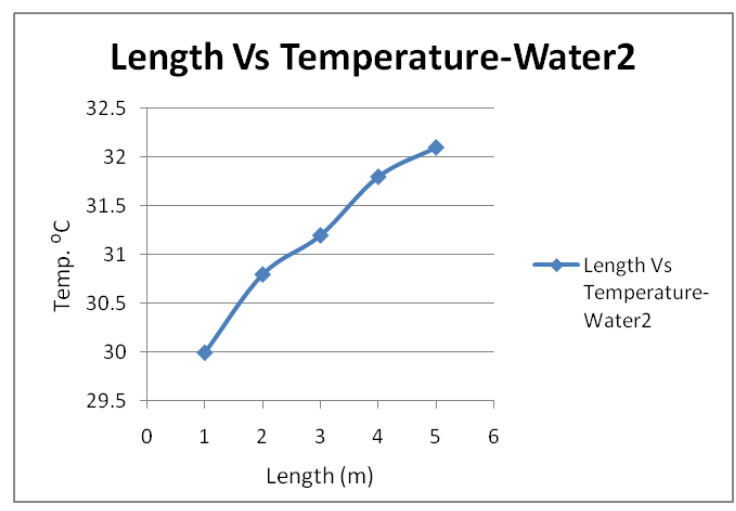

Figure 10 Temperature distribution of water2 along the length of heat exchanger

\section{Results and Discussion}

The Analytical, CFD and experimental results are as shown in Table 3.

Table 3 Comparison of all Temperature results $\left({ }^{\circ} \mathrm{C}\right)$

\begin{tabular}{|c|c|c|c|c|c|c|}
\hline & \multicolumn{2}{|c|}{ Analytical } & \multicolumn{2}{c|}{ CFD } & \multicolumn{2}{c|}{ Exptl } \\
\hline Area & $\mathrm{T}_{\text {in }}$ & $\mathrm{T}_{\text {out }}$ & $\mathrm{T}_{\text {in }}$ & $\mathrm{T}_{\text {out }}$ & $\mathrm{T}_{\text {in }}$ & $\mathrm{T}_{\text {out }}$ \\
\hline $\begin{array}{c}\text { Water1 } \\
\text { (inner } \\
\text { tube) }\end{array}$ & 30 & 31.5 & 30 & 31.3 & 30.6 & $\begin{array}{c}31 . \\
5\end{array}$ \\
\hline $\begin{array}{c}\text { Oil (inner } \\
\text { annulus) }\end{array}$ & 85 & 55 & 85 & 51.3 & 86 & 53 \\
\hline $\begin{array}{c}\text { Water2 } \\
\text { (outer } \\
\text { annulus) }\end{array}$ & 30 & 31.5 & 30 & 32.6 & 30.5 & $\begin{array}{c}32 . \\
1\end{array}$ \\
\hline
\end{tabular}

The reasons of minute difference between the results might be due to following-

1) In experimentation there was additional area occupied due to PT100 Class A temperature sensor wires which were $3 \mathrm{~m}$ long Teflon cables.

2) The inlet temperatures also show minute deviation.

3) Additional turbulence might have occurred due PT100 Class A temperature sensor points inside the tubes.

4) CFD was considered in the fully developed flow area i.e. the entrance length was not considered.

5) Entrance length is very well considered during fabrication, thus, the length is a bit greater than 1.8 $\mathrm{m}$.

6) Negligible heating errors by heaters at inputs.

7) Other surrounding environmental conditions.

\section{Conclusion}

The errors we get in CFD analysis with respect to analytical calculations are $6.7 \%$. The errors in experimental investigation with respect to analytical calculations are $5.45 \%$. These errors are tolerable as the assumptions considered are not practically achievable. From the present study, we can conclude that CFD results and the Experimental results were very much in agreement with the analytical calculations and our design is a success. Thus, use of CFD is very helpful in fabrication of heat transfer related equipments.

\section{References}

G. A. Quadir, Saqab S. Jarallah, N. J. Salman Ahmed, Irfan Anjum Badruddin; Numerical investigation of the performance of a triple concentric pipe heat exchanger, International Journal of Heat and Mass Transfer 75, 2014, pp. 165-172.

0. García-Valladares, Numerical simulation of triple concentric-tube heat exchangers, International Journal of Thermal Sciences 43, 2004, pp. 979-991.

G.A. Quadir, N. J. Salman Ahmed, Irfan Anjum Badruddin; Experimental investigation of the performance of a triple concentric pipe heat exchanger, International Journal of Heat and Mass Transfer 62, 2014, pp. 562-566. 
Birol Basal, Ahmet Unal, Numerical evaluation of a triple concentric-tube latent heat thermal energy storage, Solar Energy 92, 2013, pp. 196-205.

S. Kakac, H. Liu, Heat Exchangers, Selection, Rating, and Thermal Design, CRC Press, New York, 1998, pp. 283-328

Yusuf Ali Kara, Ozbilen Guraras, A computer program for designing of shell-and-tube heat exchangers, Applied Thermal Engineering 24, 2004, pp. 1797-1805.

M. Bernardi, V. Silveira Jr., V. R. N. Telis, A. L. Gabas and J. Telis-Romero; Forced Convection To Laminar Flow Of Liquid Egg Yolk In Circular And Annular Ducts, Brazilian Journal of Chemical Engineering, Vol.26, No.02, 2009, pp.297-298.

Ashis K. Datta, Heat transfer coefficient in laminar flow of non-Newtonian fluid in tubes, Journal of Food Engineering 39, 1999, pp. 285-287

Geankoplis, C. J., 1993, Transport process and unit operations (3rded.), Englewood Clifs, NJ, USA: Prentice-Hall, pp. 297

E. Batmaz, K.P. Sandeep, Calculation of overall heat transfer coefficients in a triple tube heat exchanger, Heat Mass Transfer 41, 2005, pp. 271-279.

F.P. Incropera, D.P. DeWitt, Fundamentals of Heat and Mass Transfer, third ed., Wiley, New York, 1990, pp. 183-213

E.M. Smith, Thermal Design of Heat Exchangers, Wiley, West Sussex, 1997.

A. Unal, Theoretical analysis of triple concentric-tube heat exchangers part 1: mathematical modelling, Int. Commun. Heat Mass Transfer 25, 1998, pp. 949-958.

A. Unal, Theoretical analysis of triple concentric-tube heat exchangers part 2: case studies, Int. Commun. Heat Mass Transfer 28, 2001, pp. 243-256.

P. Nema, A.K. Datta, Improved milk fouling simulation in a helical triple tube heat exchanger, Int. J. Heat Mass Transfer 49, 2006, pp. 3360-3370.
N.H. Saeid, K.N. Seetharamu, Finite element analysis for cocurrent and counter-current parallel flow three-fluid heat exchanger, Int. J. Numer. Methods Heat Fluid Flow 16, 2006, pp. 324-337.

V. Krishna, P.G. Hegde, N. Subramanian, K.N. Seetharamu Effect of ambient heat-in-leak on the performance of a three fluid heat exchanger, for cryogenic applications, using finite element method, Int. J. Heat Mass Transfer 55, 2012, pp.5459-5470.

V. Krishna, S. Spoorthi, P.G. Hegde, K.N. Seetharamu, Effect of longitudinal wall conduction on the performance of a three-fluid cryogenic heat exchanger with three thermal communications, Int. J. Heat Mass Transfer 62, 2013, pp. 567-577.

R. W. Lewis, P. Nithiarasu, K.N. Seetharamu, Fundamentals of the Finite Element Method for Heat and Fluid Flow, Wiley, New York, 2004, pp. 145-153

Patel Dharmik A., V. D. Dhiman, Jignesh J. Patel, Ravi Engineer, (2015), CFD analysis of triple concentric tube heat exchanger, University Journal of Research, 01, 30-44.

Tejas M. Ghiwala, Dr. V. K. Matawala, (2014), Sizing of triple concentric pipe heat exchanger, International Journal of Engineering Development and Research, 02, 1683-1692.

Vishwa Mohan Behera, D.H. Das, Ayushman Nayak, (2014), Numerical analysis of triple tube heat exchanger using ansys, (2014) International Journal of Scientific \& Engineering Research, 05, 1226-1231.

S. Kakac, H. Liu (1998), Heat Exchangers, Selection, Rating, and Thermal Design, CRC Press, New York, pp. 283-328.

Richard H. Pletcher, John C. Tannehill, Dale A. Anderson, (2013), Computational Fluid Mechanics and Heat Transfer, CRC Press, Third Edition. 